\title{
MIR205 Gene
}

National Cancer Institute

\section{Source}

National Cancer Institute. MIR205 Gene. NCI Thesaurus. Code C81754.

This gene is involved in the regulation of gene expression and plays a role in the development of squamous cell and breast carcinomas. 